\title{
Combined deep sampling and mass-based approaches to assess soil carbon and nitrogen losses due to land-use changes in karst area of southwestern China
}

\author{
Yecui $\mathrm{Hu}^{1}$, Zhangliu $\mathrm{Du}^{2}$, Qibing Wang ${ }^{3}$, and Guichun $\mathrm{Li}^{2}$ \\ ${ }^{1}$ School of Land Science and Technique, China University of Geosciences, Beijing, 100083, China \\ ${ }^{2}$ Institute of Environment and Sustainable Development in Agriculture, Chinese Academy of Agricultural Sciences, \\ Beijing 100081, China \\ ${ }^{3}$ Institute of Botany, Chinese Academy of Sciences, Beijing, 100093, China
}

Correspondence to: Zhangliu Du (duzhangliu@caas.cn)

Received: 25 March 2016 - Published in Solid Earth Discuss.: 6 April 2016

Revised: 17 June 2016 - Accepted: 24 June 2016 - Published: 18 July 2016

\begin{abstract}
The conversion of natural vegetation to humanmanaged ecosystems, especially the agricultural systems, may decrease soil organic carbon (SOC) and total nitrogen (TN) stocks. The objective of present study was to assess SOC and TN stocks losses by combining deep sampling with mass-based calculations upon land-use changes in a typical karst area of southwestern China. We quantified the changes from native forest to grassland, secondary shrub, eucalyptus plantation, sugarcane and corn fields (both defined as croplands), on the SOC and TN stocks down to $100 \mathrm{~cm}$ depth using fixed-depth (FD) and equivalent soil mass (ESM) approaches. The results showed that converting forest to cropland and other types significantly led to SOC and TN losses, but the extent depended on both sampling depths and calculation methods selected (i.e., FD or ESM). On average, the shifting from native forest to cropland led to SOC losses by 19.1, 25.1, 30.6, 36.8 and $37.9 \%$ for the soil depths of 0-10, 0-20, 0-40, 0-60 and 0-100 cm, respectively, which highlighted that shallow sampling underestimated SOC losses. Moreover, the FD method underestimated SOC and TN losses for the upper $40 \mathrm{~cm}$ layer, but overestimated the losses in the deeper layers. We suggest that the ESM together with deep sampling should be encouraged to detect the differences in SOC stocks. In conclusion, the conversion of forest to managed systems, in particular croplands significantly decreased in SOC and TN stocks, although the effect magnitude to some extent depended on sampling depth and calculation approach selected.
\end{abstract}

\section{Introduction}

Land-use change, like deforestation has become a significant concern in terms of environmental degradation and global climate change (Harris et al., 2012; Mukhopadhyay et al., 2016; Wiesmeier et al., 2015). Globally, the large-scale conversions of natural ecosystems to croplands and other managed ecosystems have already resulted in historically large emissions of $\mathrm{C}$ into the atmosphere (as higher as $320 \mathrm{Pg} \mathrm{C}$ ), since the dawn of settled agriculture (Lal, 2010). In turn, land degradation due to soil organic C (SOC) loss may damage ecosystem services and functions (Brevik et al., 2015; Costantini et al., 2016; Foley et al., 2005), directly affecting the hydrological and biogeochemical cycles in the earth system (Brevik et al., 2015; García-Díaz et al., 2016; Sonneveld et al., 2016). Thus, the changes in quality and quantity of SOC may inevitably influence the soil degradation, agricultural productivity and food security (Carter, 2002; Janzen, 2015; Srinivasarao et al., 2014).

Many studies have shown serious decreases of soil organic matter (SOM) pools owing to human activities, such as cultivation of soils under forest or natural vegetation (Lal, 2009; Post and Kwon, 2000). However, most soil C studies have focused only on the surface layers (i.e., $\leq 30 \mathrm{~cm}$ ) to clarify the SOC in response to land-use changes (Baker et al., 2007; Post and Kwon, 2000; Wei et al., 2014; West and Post, 2002). Because more than one-third of roots and more than one-half of soil C are stored below $20 \mathrm{~cm}$ depth (Jobbágy and Jackson, 2000), the conversion of land use change may well influ- 

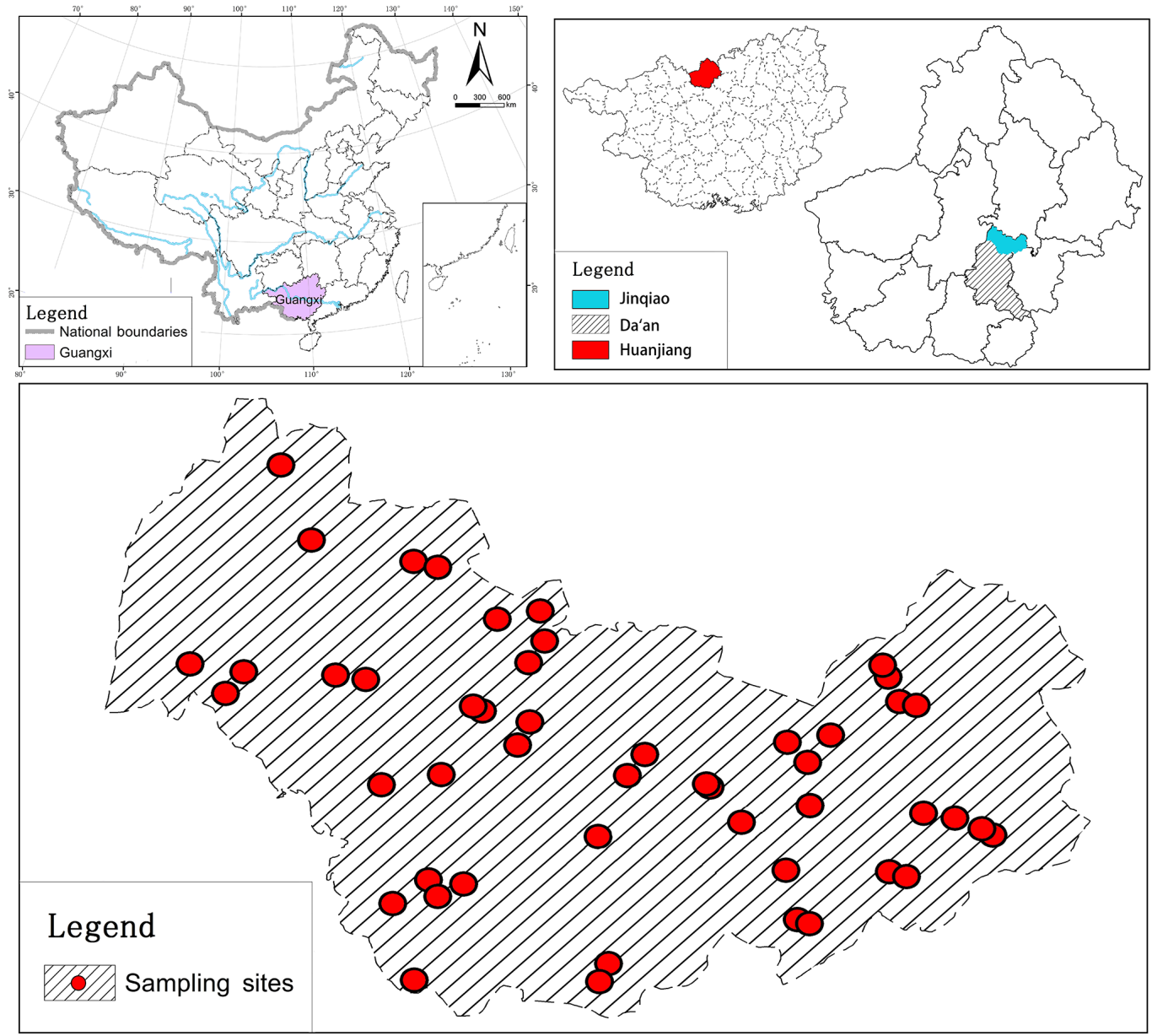

Figure 1. Location of the study area and the distribution of soil sampling sites in northwest Guangxi, southwestern China (Note: the sampling sites plotted in map do not represent the true numbers of sampling sites).

ence soil $\mathrm{C}$ in the subsoil. Therefore, the soil $\mathrm{C}$ stored in the deeper layers may be heavily neglected, but little is known about the quantity of SOC at depth and how it responds to land management (Guo and Gifford, 2002; Lozano-García and Parras-Alcántara, 2014; Wei et al., 2014). A more complete and accurate evaluation of management effects on SOC stocks should involve collecting deeper depths to identify the real changes (Baker et al., 2007; Olson and Al-Kaisi, 2015; Parras-Alcántara et al., 2015).

The SOC stock is widely quantified to a fixed-depth (FD) as the product of soil bulk density (BD), depth and concentration. This FD method, however, has been considered to introduce substantial errors when soil BD differs between treatments (VandenBygaart and Angers, 2006). Instead, equivalent soil mass (ESM) approach is required to correct the calculation (Ellert and Bettany, 1995; Lee et al., 2009). The ESM method, which can account for the differences in soil masses among treatments, is being increasingly employed (Don et al., 2011; Wiesmeier et al., 2015). As land-use conversions are often associated with the changes in soil BD, depth-based method would result in a considerable difference in soil masses for the quantification of SOC stocks.

Karst is a distinctive topography, and the rocky desertification has become a serious environmental issue in this landscape of Guangxi Province, southwestern China (Wang et al., 2004; Zhao et al., 2014). The typical karst areas are characterized by high fragility own to their natural settings and anthropogenic impacts (Xu and Zhang, 2014). This, in turn, has not only damaged eco-environment including soil erosion, lower biodiversity and decreased soil productivity, but also exacerbated the poverty level in the rural areas of the region (Hu et al., 2014; Liu et al., 2005; Wang et al., 2004). Thus, karst area is considered to be of small environmental capacity, which is characterized by its anti-disturbance, low stability and powerless self-adjustment properties.

Since the late 1990s, China initiated the Grain for Green project, and the karst region of southwestern China is one of the main regions involved in this project. Accordingly, the Guangxi governments had implemented an environmental resettlement program that transferred about 4 million people 
from this rocky region to the "in-migration" areas (Hu et al., 2008). The natural and land ecosystems in the in-migration areas exerted by ecological migrants might be negatively influenced. It is critically important to evaluate the changes in SOM status, which are accompanied by changes in ecosystem services, processes, and functions (Carter, 2002; Smith et al., 2015). We hypothesized that the ecological resettlement program may deplete SOM stocks, and thus cause soil degradation. Recently, some researchers have paid more attention about the effect of land use change on the soil physicochemical properties and soil quality in this karst region $(\mathrm{Fu}$ et al., 2015; Hu et al., 2014; Xie et al., 2015; Xu et al., 2008). However, studies on soil $\mathrm{C}$ dynamics were mainly focused on the surface layers (e.g., $\leq 30 \mathrm{~cm}$ ), and the FD method is utilized to assess SOC stocks (Chen et al., 2012; Fu et al., 2015; Liu et al., 2015b; Zhang et al., 2012). Very little effort has been devoted to the effect of land conversion on SOC stocks in the deeper soils. Thus, the present study was aimed to (1) quantify the changes in SOC and TN stocks down to $100 \mathrm{~cm}$ after conversion from native forest to croplands and other managed systems; (2) to examine whether the calculation methodology (i.e., ESM vs. FD) may change the interpretation of the results.

\section{Materials and methods}

\subsection{Study area}

This study was conducted at the Huanjiang County $\left(107^{\circ} 51^{\prime}-108^{\circ} 43^{\prime} \mathrm{E}, 24^{\circ} 44^{\prime}-25^{\circ} 33^{\prime} \mathrm{N}\right)$, Guangxi Province, southwestern China (Fig. 1). This county is surrounded by mountains, and has a total land area of $4572 \mathrm{~km}^{2}$ with elevation ranging from 149 to $1693 \mathrm{~m}$. The natural vegetation mainly consisted of shrubs, herbs, and lianas. The region is characterized by a subtropical monsoon climate with a distinct rainy (from April to September) and dry season. The annual mean temperature is $19.9^{\circ} \mathrm{C}$, and the annual average precipitation is $1750 \mathrm{~mm}$. The rainfall was unevenly distributed and concentrated during rainy seasons (about 70\%) from April to September. The soil type in investigated area is yellow soil (following the Chinese soil classification), which is formed by carbonate rock weathering. Following the US soil classification system, the yellow soil may be classified as ultisol (Gong, 1999).

Since 1999, the Huanjiang county has received about 70000 ecological migrants, and became the largest environmental resettlement region in the southwestern karst area. In this region, we selected five ecosystems, i.e., native forest (NF), unused grassland (UG), secondary shrub land (SS), eucalyptus forest (EF) and croplands (including sugarcane field: SF and corn field: $\mathrm{CF}$ ). The latter four ecosystems are all originated from the native forest due to deforestation or land-use change. All the five ecosystems selected are adjacent to each other. Within each land-use type, five plots (abut
$0.067-0.10$ ha) were chosen. All sites were located on similar physiographical conditions (e.g., with slope about 15$25^{\circ}$, and elevation) and the distance between sampling sites ranged about from 250 to $350 \mathrm{~m}$. The detailed information for the land-use types including vegetation, dominant plant species and management history is listed in Table 1.

\subsection{Soil samples collection and analysis}

All samples were taken from July to August 2012. Before soil sampling, each plot was divided into five subplots and samples were collected using an auger $(4.1 \mathrm{~cm}$ diameter $)$ down to $100 \mathrm{~cm}(0-10,10-20,20-40,40-60,60-80$, and $80-100 \mathrm{~cm}$ ) after removing the litter layer if available. Five samples were taken randomly in an "S" form at each sampling subplot, and then were composited together to gain a representative sample at each depth. Soil bulk density (BD) was measured in all six layers using sample rings $(5 \mathrm{~cm}$ in diameter and $100 \mathrm{~cm}^{3}$; soil sample ring kit, Eijkelkamp, Holland). The core samples were oven-dried at $105^{\circ} \mathrm{C}$ for $24 \mathrm{~h}$ and then weighed. A total of 150 sampling sites were investigated, and 180 combined soil samples (including six layers down to $100 \mathrm{~cm}$ depth) were collected. All samples were sieved through a $2 \mathrm{~mm}$ screen, and roots and other coarse debris fractions were removed. A portion of the samples were air-dried and stored at room temperature for soil physicochemical analysis. Another portion of samples for microbial biomass mass analyses was stored at $4{ }^{\circ} \mathrm{C}$ for no longer than one week before analyzing.

Soil organic C was analyzed with the Walkley and Black's dichromate oxidation method and total soil $\mathrm{N}$ was determined via the semi-micro Kjeldahl digestion procedure. Soil available phosphorus (AP) was extracted with $0.5 \mathrm{M}$ $\mathrm{NaHCO}_{3}$ at a pH of 8.5 and was analyzed with a colorimetric method. The above-mentioned soil $\mathrm{C}, \mathrm{N}$, and $\mathrm{P}$ analysis was measured according to (Bao, 2000). Soil texture analysis was determined by a pipette method and the soil particle was divided into three fractions according to USDA classification system: sand $2-0.05 \mathrm{~mm}$, silt $0.05-0.002 \mathrm{~mm}$ and clay $<0.002 \mathrm{~mm}$. The soil microbial biomass carbon (SMC) was measured by chloroform fumigation- $\mathrm{K}_{2} \mathrm{SO}_{4}$ extraction carbon automatic analysis (Wu et al., 2006).

\subsection{Soil organic $\mathbf{C}$ and total $\mathbf{N}$ calculations}

We calculated SOC and TN stocks on both FD and ESM basis. The principle of ESM method is given by (Ellert and Bettany, 1995; Lee et al., 2009). When soils are sampled to the designated depth $(i=1, \ldots, n)$, the soil mass is calculated as follows:

$M_{i}=\mathrm{BD}_{i} \times Z_{i} \times 100$,

where $M_{i}$ is dry soil mass $\left(\mathrm{Mg} \mathrm{ha}^{-1}\right), \mathrm{BD}_{i}$ is soil bulk density $\left(\mathrm{g} \mathrm{cm}^{-3}\right), Z_{i}$ is the thickness of the $i$ th soil layer $(\mathrm{cm})$, and 100 is a unit conversion factor. The SOC stock in the fixed 
Table 1. The general information of land-use types selected in this study.

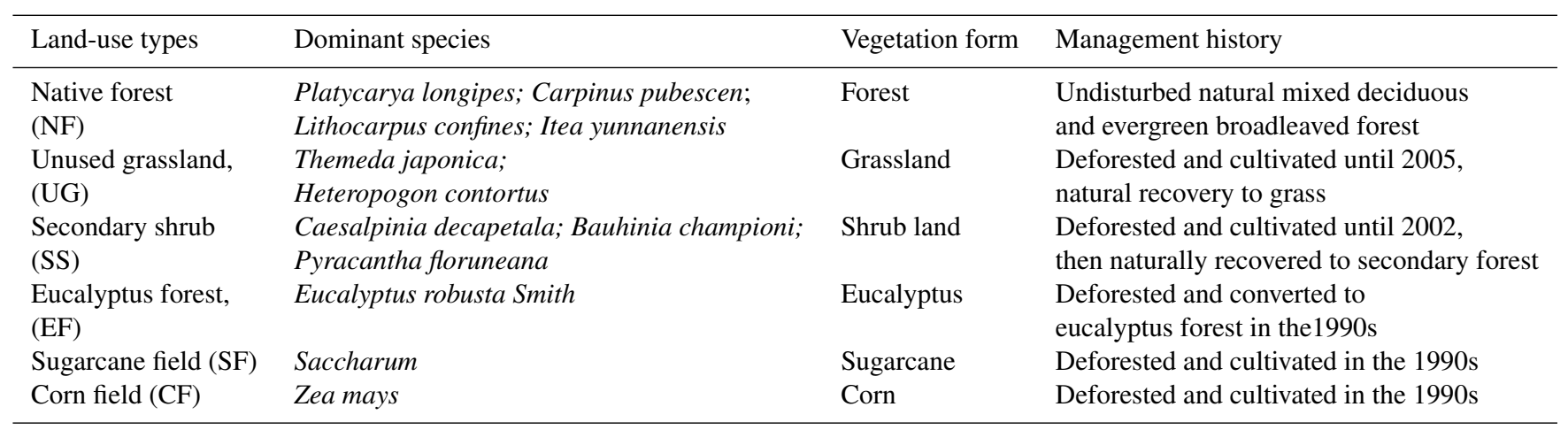

depth was calculated as follows:

$\mathrm{SOC}_{i, \mathrm{fixed}}=\mathrm{Con}_{i} \times M_{i} \times 0.1$,

where $\mathrm{SOC}_{i \text {, fixed }}$ is the SOC mass to a fixed layer $\left(\mathrm{Mg} \mathrm{ha}^{-1}\right)$ and $\mathrm{Con}_{i}$ is the SOC concentration $\left(\mathrm{g} \mathrm{kg}^{-1}\right), 0.1$ is a unit conversion factor. Hence, the equivalent $\mathrm{C}$ mass $\left(\mathrm{Mg} \mathrm{ha}^{-1}\right)$ in a soil layer is calculated as follows:

$$
\begin{aligned}
M_{i, \text { ex }} & =M_{i}-M_{i, \text { equiv }} \\
\mathrm{SOC}_{i, \text { equiv }} & =\mathrm{SOC}_{i, \text { fixed }}-\left(\mathrm{Con}_{\text {bottom }} \times M_{i, \mathrm{ex}}\right) / 1000,
\end{aligned}
$$

where $\mathrm{SOC}_{i, \text { equiv }}$ is the equivalent $\mathrm{SOC}$ mass $\left(\mathrm{Mg} \mathrm{ha}^{-1}\right)$, $M_{i, \text { equiv }}$ is the selected equivalent soil mass, $M_{i, \text { ex }}$ is the excess soil mass used to attain the ESM, Con bottom is SOC concentration in the deepest soil core segment $\left(\mathrm{g} \mathrm{C} \mathrm{kg}^{-1}\right.$ soil; core segment $=n), 1000$ is a unit conversion factor. The TN stock was calculated using the same procedure as described above. We designated the lightest soil mass among the treatments for the specific layer as equivalent soil mass according to (Lee et al., 2009).

\subsection{Statistical analysis}

Analysis of variance was performed using the SPSS 11.0 software (SPSS, 2001) to compare the differences in SOC and TN concentrations and stocks, SMC, AP, and soil BD among different land-use types or soil depths. Before performing an analysis of variance, the normality of the data was tested using the Shapiro-Wilk method with Sigma Plot (version 12.5, Systat Software Inc.). The means were compared using Fisher's protected least significant difference (LSD). Unless otherwise stated, all differences discussed are significant at the $P<0.05$ probability level.

\section{Results}

\subsection{Selected soil physicochemical properties}

For the $0-40 \mathrm{~cm}$ depth, the averaged SOC concentration was in the order of $\mathrm{NF}>\mathrm{UG}>\mathrm{SS}=\mathrm{EF}$, and $\mathrm{SS}>\mathrm{SF}=\mathrm{CF}$, in- dicating deforestation significantly reduced SOC level, particularly converted into the croplands (Table 2). Similarly, the highest TN concentration was found under NF, and followed by UG and SS, and the lowest was EF, SF, and CF. The SMC concentration was also different between land uses $(P<0.05)$, and were significantly greater in the native forest than in the other land-use types. However, the averaged soil BD and available phosphorus (AP) under different ecosystems did not exhibit significantly differences (Table 2). The clay and silt contents ranged from 21.3 to $30.4 \%$, and from 18.9 to $27.0 \%$, respectively, among the six land-use types. Except for the two agricultural soils (SF and CF) that belonged to the clay loam soil, the other four land-use types all were sandy clay loam soils.

\subsection{Soil BD, SOC and TN concentrations across soil profile}

Two-way ANOVA showed that land-use types and soil depths significantly impacted soil BD, SOC and TN concentrations and stocks $(P<0.001$; Table 3$)$. We also observed their interactive effects for all the measured parameters ( $P<0.001$; only for soil BD, $P=0.03$ ). Soil BD was higher under $\mathrm{CF}$ and $\mathrm{SS}$ than that of NF in $0-10 \mathrm{~cm}$ layer. In the $10-20 \mathrm{~cm}$ depth, the highest value was found in the $\mathrm{CF}$ soil, while the lowest occurred under SF. Below the $40 \mathrm{~cm}$ layer, limited differences were observed among different land-use types (Fig. 2). Soil BD generally ranged from 1.22 to $1.69 \mathrm{~g} \mathrm{~cm}^{-3}$ from surface to bottom layers, showing increasing tendency across soil profile irrespective of landuse types (Fig. 2). Overall, soil BD was lower in upper 0 $40 \mathrm{~cm}$ layers as compared with that in the deeper layers. The changes in soil BD across the soil profile might bias the interpretation of SOC stocks calculated on the FD basis.

There was a significant interaction between land-use types and depths on SOC and TN concentrations $(P<0.001$; Table 3). Overall, SOC and TN concentrations generally decreased with depths across soil profile (Fig. 3). The highest value was observed in NF soil, while the difference among NF, UG and SS soils was not significant $(P>0.05)$ in the 
Table 2. Selected soil physicochemical properties for the different land-use types $(0-40 \mathrm{~cm})$.

\begin{tabular}{|c|c|c|c|c|c|c|c|}
\hline \multirow[b]{2}{*}{ Variable } & \multicolumn{6}{|c|}{ Land-use types } & \multirow[b]{2}{*}{$F$ value } \\
\hline & NF & UG & SS & $\mathrm{EF}$ & SF & $\mathrm{CF}$ & \\
\hline $\mathrm{SOC}\left(\mathrm{g} \mathrm{kg}^{-1}\right)$ & $15.76 \pm 0.42 \mathrm{a}$ & $13.95 \pm 0.35 b$ & $12.40 \pm 0.40 \mathrm{c}$ & $11.47 \pm 0.33 \mathrm{~cd}$ & $11.28 \pm 0.23 \mathrm{~d}$ & $10.99 \pm 0.46 \mathrm{~d}$ & $25.02^{* *}$ \\
\hline $\mathrm{TN}\left(\mathrm{g} \mathrm{kg}^{-1}\right)$ & $1.53 \pm 0.07 \mathrm{a}$ & $1.25 \pm 0.04 b$ & $1.17 \pm 0.04 \mathrm{~b}$ & $1.02 \pm 0.03 \mathrm{c}$ & $1.02 \pm 0.02 \mathrm{c}$ & $0.98 \pm 0.03 c$ & $22.35^{* *}$ \\
\hline $\mathrm{AP}\left(\mathrm{mg} \mathrm{g}^{-1}\right)$ & $0.129 \pm 0.01 \mathrm{a}$ & $0.109 \pm 0.01 \mathrm{a}$ & $0.091 \pm 0.01 \mathrm{a}$ & $0.088 \pm 0.01 \mathrm{a}$ & $0.104 \pm 0.01 \mathrm{a}$ & $0.097 \pm 0.01 \mathrm{a}$ & $2.46 \mathrm{~ns}$ \\
\hline $\operatorname{SMC}\left(\mathrm{mg} \mathrm{kg}^{-1}\right)$ & $257 \pm 25 \mathrm{a}$ & $134 \pm 5 b$ & $143 \pm 2 b$ & $111 \pm 11 b$ & $106 \pm 8 b$ & $119 \pm 13 c$ & $24.64^{*}$ \\
\hline $\mathrm{BD}\left(\mathrm{g} \mathrm{cm}^{-3}\right)$ & $1.36 \pm 0.06 \mathrm{a}$ & $1.41 \pm 0.02 \mathrm{a}$ & $1.48 \pm 0.04 \mathrm{a}$ & $1.42 \pm 0.04 \mathrm{a}$ & $1.32 \pm 0.06 \mathrm{a}$ & $1.48 \pm 0.04 \mathrm{a}$ & $1.99 \mathrm{~ns}$ \\
\hline Clay $(\%)$ & 21.3 & 21.9 & 24.8 & 25.5 & 31.0 & 30.4 & - \\
\hline Silt (\%) & 20.1 & 18.9 & 25.2 & 27.0 & 24.2 & 24.9 & - \\
\hline $\operatorname{Sand}(\%)$ & 58.6 & 59.2 & 50.0 & 47.5 & 44.8 & 44.7 & - \\
\hline Soil texture & Sandy clay loam & Sandy clay loam & Sandy clay loam & Sandy clay loam & Clay loam & Clay loam & - \\
\hline
\end{tabular}

Note: NF, native forest; UG, unused grassland; SS, secondary shrub; EF, eucalyptus forest; SF, sugarcane field; CF, corn field; SOC, soil organic carbon content; TN, total nitrogen; AP, available phosphorus; SMC, soil microbial biomass carbon concentration. BD, soil bulk density; clay, soil clay $(<0.002 \mathrm{~mm})$; silt, soil silt $(0.05-0.002 \mathrm{~mm})$; sand, soil sand $(2.0-0.05 \mathrm{~mm})$; different letters following values indicate significance at $P=0.05 ; \mathrm{ns},{ }^{*},{ }^{*}$, no significant difference at $P=0.05,<0.05,<0.01$, respectively $(N=5)$.

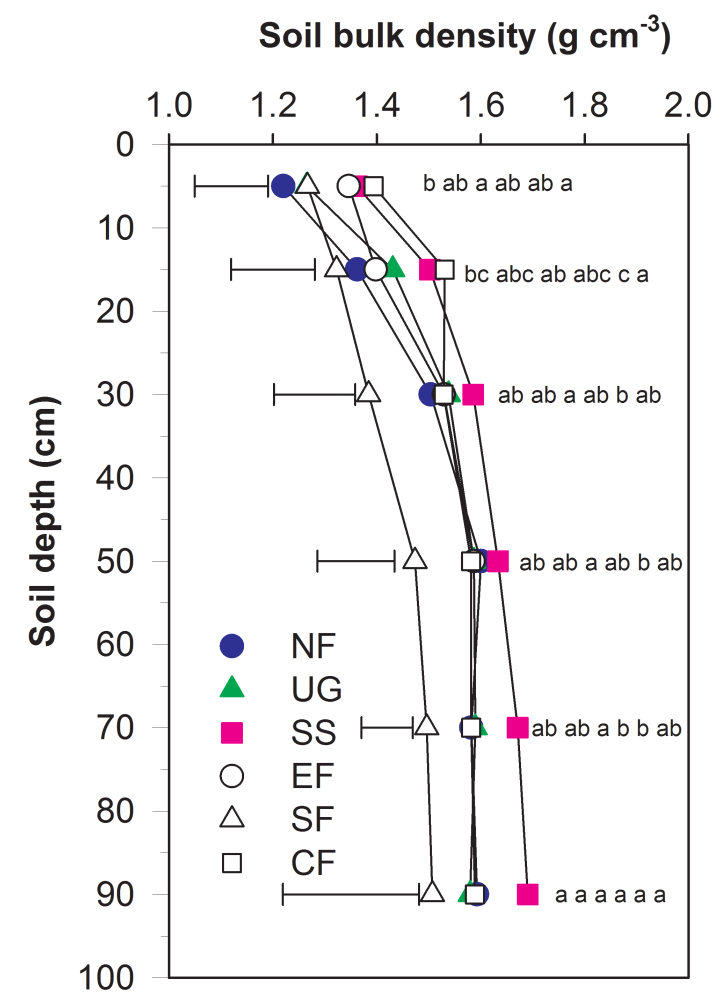

Figure 2. Changes in soil bulk density along soil profile under different land uses types (NF, native forest; UG, unused grassland; SS, secondary shrub; EF, eucalyptus forest; SF, sugarcane field; $\mathrm{CF}$, corn field). Error bars represent LSD calculated by one-way ANOVA at $P=0.05$ level $(N=5)$, and different lowercase letters indicate significant changes between land-use types within soil depth (Note: letters from left to right stand for NF, UG, SS, EF, SF and $\mathrm{CF}$, respectively).

$0-10 \mathrm{~cm}$ layer. Afterwards, a sharp and significant decline happened in the $10-20 \mathrm{~cm}$ layer (Fig. 3). In the $20-40 \mathrm{~cm}$ layer, SOC concentration under NF and UG were greater than those in other ecosystems, whereas no changes in SOC and $\mathrm{N}$ concentrations existed between SS, EF, SF and CF soils. Similarly, the TN concentration followed the order of $\mathrm{NF}>\mathrm{UG}=\mathrm{SS}>\mathrm{EF}=\mathrm{SF}=\mathrm{CF}$. At the deeper layers (i.e., $40-60,60-80$, and $80-100 \mathrm{~cm}$ ), both SOC and TN concentrations greatly decreased from native forest to other managed ecosystems (Fig. 3).

\subsection{Soil organic C and TN stocks calculated on FD and ESM basis}

The SOC and TN stocks calculated on FD and ESM basis are presented in Table 4. On the FD basis, no differences in SOC stock between land-use types were found in the 0 $10 \mathrm{~cm}$ layer $(P>0.05$; Table 4$)$, except for the SS, which had higher SOC stock than SF. In the 0-20 cm layer, NF had higher SOC stock by 31.8 and $23.0 \%$ than that of SF and CF treatments, respectively. Taken together the $0-40 \mathrm{~cm}$ depth, the $\mathrm{SOC}$ stock was in the order of $\mathrm{NF}=\mathrm{UG}>\mathrm{SS}=\mathrm{EF}$, and $\mathrm{SS}>\mathrm{SF}=\mathrm{CF}$, and NF increased SOC by 50.2 and $36.4 \%$ than $S F$ and $C F$ respectively. Instead, for the $0-60 \mathrm{~cm}$ profile, SOC stock showed a trend of $\mathrm{NF}>\mathrm{UG}>\mathrm{SS}>\mathrm{EF}=\mathrm{SF}=\mathrm{CF}$, and the SOC under NF was higher by 14.0, 25.5, 49.6, 64.4 and $59.1 \%$ than that of UG, SS, EF, SF and CF, respectively. Similar trend of SOC stock induced by land use conversion was found in the $0-100 \mathrm{~cm}$ profile. These data indicated that the SOC stocks changes heavily depended on the soil sampling depth considered. The TN at different soil depths shared a similar pattern with the SOC in these ecosystems.

On the ESM basis, the highest SOC stock stored in the NF soil of the $0-10 \mathrm{~cm}$ layer $\left(\approx 1220 \mathrm{Mg} \mathrm{ha}^{-1}\right)$. Compared with NF, the SOC stock in this layer was reduced by $7.3 \%$ under UG, $6.9 \%$ under SS and $19.6 \%$ under $\mathrm{CF}$, though the differences between NF, UG and SS were not significant $(P>0.05$; Table 4$)$. For the $0-20 \mathrm{~cm}$ depth $\left(\approx 2582 \mathrm{Mg} \mathrm{ha}^{-1}\right)$, the SOC stock showed an order of $\mathrm{NF}>\mathrm{UG}=\mathrm{SS}$, and $\mathrm{UG}>\mathrm{EF}=\mathrm{SF}=\mathrm{CF}$. Specifically, $\mathrm{SOC}$ stock was lower by $11.7,16.7$ and $20.6 \%$ following the shift from NF to UG, SS, and CF, respectively. Under the $0-40 \mathrm{~cm}$ profile selected $\left(\approx 5357 \mathrm{Mg} \mathrm{ha}^{-1}\right)$, the averaged SOC stock 
Table 3. Results ( $P$ values) of two-way ANOVAs on the effects of land-use types, soil depth and their interaction on soil bulk density (BD), soil organic $\mathrm{C}(\mathrm{SOC})$ and total nitrogen $(\mathrm{TN})$ concentrations and stocks.

\begin{tabular}{lrrrrr}
\hline & BD & $\begin{array}{r}\text { SOC } \\
\text { concentration }\end{array}$ & $\begin{array}{r}\text { TN } \\
\text { concentration }\end{array}$ & $\begin{array}{r}\text { SOC } \\
\text { stock }\end{array}$ & $\begin{array}{r}\text { TN } \\
\text { Stock }\end{array}$ \\
\hline Land use & $<0.001$ & $<0.001$ & $<0.001$ & $<0.001$ & $<0.001$ \\
Soil depth & $<0.001$ & $<0.001$ & $<0.001$ & $<0.001$ & $<0.001$ \\
Land use $\times$ soil depth & 0.03 & $<0.001$ & $<0.001$ & $<0.001$ & $<0.001$ \\
\hline
\end{tabular}
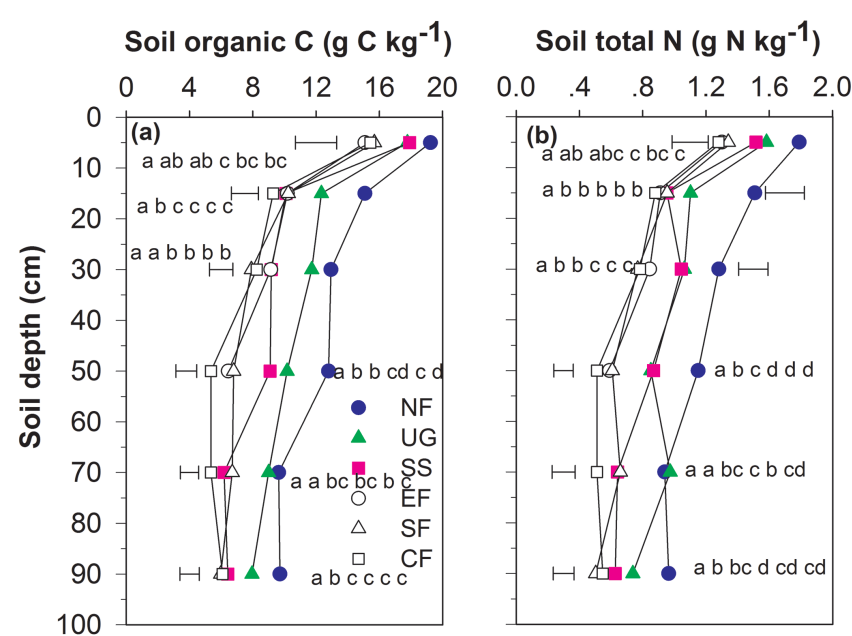

Figure 3. Vertical distribution of soil organic $\mathrm{C}$ (a) and total $\mathrm{N}$ (b) concentrations as influenced by changes in land-use types (NF, native forest; UG, unused grassland; SS, secondary shrub; $\mathrm{EF}$, eucalyptus forest; SF, sugarcane field; CF, corn field). Error bars represent LSD calculated by one-way ANOVA at $P=0.05$ level $(N=5)$, and different lowercase letters indicated significant changes between land-use types within soil depth (Note: letters from left to right stand for NF, UG, SS, EF, SF and CF, respectively).

under NF reduced by $10.8 \%$ under $\mathrm{UG}, 22.1 \%$ under $\mathrm{SS}$ and $30.4 \%$ under CF soil. When deeper profile was considered $(\geq 60 \mathrm{~cm}$ ), for example, the SOC stored in the NF of $0-60 \mathrm{~cm}$ soil was reduced by $24.1 \%$ under SS and $37.7 \%$ under CF. For the whole $0-100 \mathrm{~cm}$ profile, the conversion from NF to SS and CF decreased SOC stocks by 26.8 and $39.8 \%$, respectively. TN stocks followed similar patterns with SOC stocks. These data indicated that sampling depth considered may impact the interpretation of SOC losses upon the land use conversion.

\section{Discussion}

\subsection{Sampling depth for assessing SOC and TN stocks}

According to our study, the SOC and TN stocks markedly decreased following native forest conversion to managed ecosystems by human activities (Table 4; Fig. 3). These re- sults are in line with findings that soil $\mathrm{C}$ and $\mathrm{N}$ stored in natural ecosystems are more than that in the converted lands (de Moraes Sá et al., 2015; Don et al., 2011; Fialho and Zinn, 2014; Guo and Gifford, 2002). In karst region of southwestern China, similar results were also reported (Chen et al., 2012; Liu et al., 2015a). Consequently, the depletion of SOM may be directly related to the loss of ecosystem services and land productivity.

It is worth noting that the effect magnitude of SOC and TN stocks losses by land-use change might partly depend on sampling depth considered. For example, the conversion from NF to CF had led to SOC loss by 19.6, 26.0 and $30.4 \%$ in the 0-10,0-20, and 0-40 cm layers, respectively (Table 4). Moreover, the decreased SOC stock loss under NF relative to CF was $36.8 \%$ in the $0-60 \mathrm{~cm}$ depth and $37.9 \%$ in the 0 $100 \mathrm{~cm}$ whole profile. The data clearly suggest that the SOC loss due to land use changes generally increased with depth. We recommend that shallow sampling may bias the interpretation of soil $\mathrm{C}$ data, and should be paid more attention in further study. Our results are supported by other studies (Baker et al., 2007; Olson and Al-Kaisi, 2015). Otherwise, if the shallow layers of soil profile only are collected, the SOC loss following land use changes might be underestimated to some extent.

In the karst area, most early reports have focused on the top soil layer (e.g., $\leq 30 \mathrm{~cm}$ ) to assess the SOC stocks changes (Chen et al., 2012; Fu et al., 2015; Liu et al., 2015b; Zhang et al., 2012). These above-mentioned works and other superficial studies on how land use changes may alter SOM dynamics (Post and Kwon, 2000; West and Post, 2002), may lead to erroneous results. As a result, the whole soil profile, rather than the tilled layer, should be sampled to capture the possible differences in SOC stocks upon land use change. Lal (2009) considered that it is important to measure the land-use-induced changes in SOC to at least $1 \mathrm{~m}$, preferably $2 \mathrm{~m}$ depth in forest systems where deep tap roots may transfer biomass $\mathrm{C}$ to deeper layers.

\subsection{Changes in SOC and TN stocks calculated by FD and ESM approaches}

In our study, the ESM method has been proposed in which soil $\mathrm{C}$ and $\mathrm{N}$ data for a fixed depth can be adjusted to normalize to a particular soil mass within specific layer (Ellert and Bettany, 1995). Overall, the patterns of SOC and TN stocks 
Table 4. Soil organic C (SOC) and total N (TN) stocks calculated using fixed-depth (FD) and equivalent soil mass (ESM) methods in different soil depths under land-uses types (NF, native forest; UG, unused grassland; SS, secondary shrub; EF, eucalyptus forest; SF, sugarcane field; $\mathrm{CF}$, corn field).

\begin{tabular}{|c|c|c|c|c|c|c|}
\hline \multirow[t]{2}{*}{$\begin{array}{l}\text { Land use } \\
\text { types }\end{array}$} & \multirow[t]{2}{*}{$\begin{array}{l}\text { Soil depth } \\
\mathrm{cm}\end{array}$} & \multicolumn{2}{|c|}{$\begin{array}{l}\text { FD-based stock } \\
\mathrm{Mg} \mathrm{ha}^{-1}\end{array}$} & \multirow[b]{2}{*}{ Soil mass } & \multicolumn{2}{|c|}{$\begin{array}{c}\text { ESM-based stock } \\
\mathrm{Mg} \mathrm{ha}^{-1}\end{array}$} \\
\hline & & SOC & $\mathrm{TN}$ & & SOC & $\mathrm{TN}$ \\
\hline $\mathrm{NF}^{*}$ & $0-10$ & $23.48 \mathrm{ab}$ & $2.18 \mathrm{a}$ & $1220 \mathrm{~b}$ & $23.48 \mathrm{a}$ & $2.18 \mathrm{a}$ \\
\hline UG & & $22.55 \mathrm{ab}$ & $2.00 \mathrm{ab}$ & $1265 \mathrm{ab}$ & $21.76 \mathrm{ab}$ & $1.93 \mathrm{ab}$ \\
\hline SS & & $24.39 \mathrm{a}$ & $2.06 \mathrm{ab}$ & $1362 \mathrm{a}$ & $21.86 a b$ & $1.85 \mathrm{abc}$ \\
\hline $\mathrm{EF}$ & & $20.27 \mathrm{ab}$ & $1.76 \mathrm{~b}$ & $1346 a b$ & $18.38 b$ & $1.59 \mathrm{bc}$ \\
\hline SF & & $19.85 b$ & $1.70 \mathrm{~b}$ & $1267 \mathrm{ab}$ & $19.12 b$ & $1.64 b c$ \\
\hline $\mathrm{CF}$ & & $21.55 \mathrm{ab}$ & $1.79 \mathrm{~b}$ & $1394 a$ & $18.87 \mathrm{~b}$ & $1.56 \mathrm{c}$ \\
\hline $\mathrm{NF}$ & $0-20$ & $43.97 \mathrm{a}$ & $4.25 \mathrm{a}$ & 2582b & $43.97 \mathrm{a}$ & $4.25 \mathrm{a}$ \\
\hline UG & & $40.21 \mathrm{ab}$ & $3.58 b$ & $2695 \mathrm{ab}$ & $38.81 b$ & $3.45 b$ \\
\hline SS & & $39.49 b c$ & $3.49 \mathrm{bc}$ & $2864 \mathrm{ab}$ & $36.64 b c$ & $3.22 b c$ \\
\hline $\mathrm{EF}$ & & $34.43 \mathrm{~d}$ & $3.02 \mathrm{~cd}$ & $2744 \mathrm{ab}$ & $32.78 \mathrm{c}$ & $2.88 \mathrm{c}$ \\
\hline SF & & $33.37 \mathrm{~d}$ & $2.96 \mathrm{~d}$ & $2589 \mathrm{~b}$ & $33.29 \mathrm{c}$ & $2.95 \mathrm{c}$ \\
\hline $\mathrm{CF}$ & & $35.73 d$ & $3.13 \mathrm{bcd}$ & $2924 a$ & $32.55 \mathrm{c}$ & $2.83 \mathrm{c}$ \\
\hline $\mathrm{NF}$ & $0-40$ & $83.00 \mathrm{a}$ & $8.09 a$ & $5589 \mathrm{ab}$ & $79.99 a$ & $7.79 a$ \\
\hline UG & & $76.20 \mathrm{a}$ & $6.83 b$ & $5771 \mathrm{ab}$ & $71.34 b$ & $6.39 b$ \\
\hline SS & & $68.54 \mathrm{~b}$ & $6.81 \mathrm{~b}$ & $6035 a$ & $62.33 \mathrm{c}$ & $6.10 \mathrm{~b}$ \\
\hline $\mathrm{EF}$ & & $62.23 b c$ & $5.60 \mathrm{c}$ & 5801ab & $58.17 \mathrm{~cd}$ & $5.23 c$ \\
\hline SF & & $55.28 \mathrm{c}$ & $5.09 \mathrm{c}$ & 5357b & $55.28 \mathrm{~d}$ & $5.09 \mathrm{c}$ \\
\hline $\mathrm{CF}$ & & $60.84 c$ & $5.52 \mathrm{c}$ & $5982 \mathrm{a}$ & $55.69 \mathrm{~d}$ & $5.03 \mathrm{c}$ \\
\hline $\mathrm{NF}$ & $0-60$ & $123.69 \mathrm{a}$ & $11.76 \mathrm{a}$ & 8791ab & $117.47 \mathrm{a}$ & $11.20 \mathrm{a}$ \\
\hline UG & & $108.46 b$ & $9.53 b$ & $8945 \mathrm{ab}$ & $101.95 b$ & $8.99 b$ \\
\hline SS & & $98.29 \mathrm{c}$ & $9.65 b$ & $9301 \mathrm{a}$ & $89.22 \mathrm{c}$ & $8.79 b$ \\
\hline $\mathrm{EF}$ & & $82.66 \mathrm{~d}$ & $7.47 \mathrm{c}$ & $8974 a b$ & $78.35 \mathrm{~d}$ & $7.08 \mathrm{c}$ \\
\hline SF & & $75.24 d$ & $6.88 \mathrm{c}$ & $8304 b$ & $75.24 d$ & $6.88 \mathrm{c}$ \\
\hline $\mathrm{CF}$ & & $77.73 d$ & $7.13 c$ & $9145 a$ & $73.23 \mathrm{~d}$ & $6.70 \mathrm{c}$ \\
\hline $\mathrm{NF}$ & $0-100$ & $185.32 \mathrm{a}$ & $17.82 \mathrm{a}$ & $15140 \mathrm{ab}$ & $177.24 \mathrm{a}$ & $17.01 \mathrm{a}$ \\
\hline UG & & $162.15 b$ & $14.96 \mathrm{~b}$ & $15283 a$ & $154.41 \mathrm{~b}$ & $14.24 b$ \\
\hline SS & & $140.68 \mathrm{c}$ & $13.92 b$ & $16024 a$ & $129.68 \mathrm{c}$ & $12.85 b$ \\
\hline $\mathrm{EF}$ & & $120.99 d$ & $10.40 \mathrm{~b}$ & $15225 \mathrm{ab}$ & $115.47 d$ & $9.98 \mathrm{c}$ \\
\hline SF & & $113.30 \mathrm{~d}$ & $10.37 \mathrm{c}$ & $14310 b$ & $113.30 \mathrm{~d}$ & $10.37 \mathrm{c}$ \\
\hline $\mathrm{CF}$ & & $113.94 \mathrm{~d}$ & $10.48 \mathrm{c}$ & $15486 a$ & $106.78 d$ & $9.84 \mathrm{c}$ \\
\hline
\end{tabular}

* Values followed by a different lowercase letter in the same row among land-use types are significant difference at $P<0.05(N=5)$. The bold form number for soil mass indicated the equivalent soil mass was chosen.

were better clarified by the ESM approach, especially in upper layers (e.g., $\leq 40 \mathrm{~cm}$; Table 4). Using the FD method, the SOC stored in the NF soil was reduced by $11.8,21.4$, $30.0,38.2$, and $38.7 \%$ in the $0-10,0-20,0-40,0-60$, and $0-$ $100 \mathrm{~cm}$ layers, respectively, as compared with the croplands (including SS and CF). By contrast, these corresponding values were 19.1, 25.1, 30.6, 36.8, and $37.9 \%$, when calculation on the ESM basis. These data indicate that FD method underestimated SOC loss in the $0-40 \mathrm{~cm}$ layer, but overestimated in the $0-60$ and $0-100 \mathrm{~cm}$ profiles, although the two groups were not statistically different (Paired $t$ test, $P=0.305$ ). The contrasting results are probably associated with the variations in soil BD across soil profile (Fig. 2). Thus, in studies that use an FD approach for the comparison of SOC stocks may misinterpret the SOC changes, which is supported by other studies (Don et al., 2011; Lee et al., 2009). Instead, ESM calculation appears to be more effective for detecting temporal trends in SOC and other nutrients stocks.

It should be noted that the calculation methods also influence SOC interpretation even in deeper profiles (e.g., 0 60 and $0-100 \mathrm{~cm}$; Table 4). This case indicates that even if deeper soil profile (e.g., $\geq 60 \mathrm{~cm}$ ) is collected, it is still necessary for ESM method to accurately assess SOC stock. Otherwise, the variations in soil $\mathrm{BD}$, which usually occurs at surface soils, may obscure changes in profile SOC stock. In a future study, we should reassess the archived soil C data us- 
ing ESM instead of FD approach, which will help to improve our ability to detect the relatively small changes in the SOM pool in response to land-use change.

\subsection{Implications for future land-use management}

Our study had shown that converting native forest towards agricultural ecosystems caused the highest SOM losses (as high as $39.8 \%$ for SOC and $42.4 \%$ for TN) down to $100 \mathrm{~cm}$ profile (Table 4; Fig. 2). Historically, any land-use changes that disrupt the prior long-standing balance of input and decay processes will induce a shift in SOC stocks (Batjes, 2014; Janzen, 2015). Almost invariably, for example, converting forest to grassland or arable cropland resulted in loss of soil C and N (Don et al., 2011; Foley et al., 2005; Guo and Gifford, 2002; Wei et al., 2014), not only because disturbance stimulates SOM decay (Post and Kwon, 2000; Six et al., 2002), but also because inputs from aboveground and belowground are reduced (Guo and Gifford, 2002). Consequently, the declined SOM might drive land degradation that directly impairs on human society through loss of ecosystem goods and services (Carter, 2002; Jaiarree et al., 2014; Lal, 2010; Smith et al., 2015). Regretfully, we did not measure the aboveground biomass and crop yields in the present study and the knowledge should be determined for productivity analysis in future investigation.

In the karst regions of southwestern China, the declined SOM had caused soil degradation, leading to the increased soil erosion and reduced land productivity (Hu et al., 2014; Liu et al., 2005; Xu et al., 2008). Xie et al. (2015) highlighted that the degradation trend of soil fertility was almost parallel to the aggravation of karst rocky desertification. Thus, how to conserve and restore the degraded karst areas is promoted by Chinese central and local governments (Hu et al., 2008; Zhao et al., 2014). Our results showed that the conversion of native forest to croplands had exported SOC from soils as higher as $39.8 \%$ (Table 4). Instead, for the unused grassland (UG) and secondary shrub (SS) ecosystems, the SOC stock was reduced by 12.8 and $26.8 \%$, respectively, compared with the native forest (NF). Based on these results, we suggest that it is necessary to conduct some engineering programs (e.g., afforestation) to accelerate SOC recovery in the karst region. A recent study by Liu et al. (2015a) found that the soil microbial activities, texture, and litter fall played important roles in SOC accumulation along vegetation successions, and relevant strategies such as increased $\mathrm{N}$ import and less soil disturbances were proposed to enhance SOC sequestration, and thus ecological restoration in this vulnerable karst landscape. Thus, further understanding of the mechanisms of SOM protection and recovery (e.g., soil aggregation, texture, and organic residues input) under land use change is heavily needed. This is particularly important in southwestern China, because of the large area of native forests being increasingly conversed to agricultural land and other human managed ecosystems.

\section{Conclusions}

Our study demonstrates that the conversion of native forest into cropland and other managed systems led to SOC and $\mathrm{TN}$ losses. However, the effect magnitude of soil $\mathrm{C}$ and $\mathrm{N}$ stocks losses were dependent on sampling depths (i.e., surface vs. subsoil) and calculation approaches. The averaged SOC stocks on ESM basis in the depths of 0-10, 0-20, 0$40,0-60$ and $0-100 \mathrm{~cm}$ of croplands (including SF and CF) were 19.1, 25.1, 30.6, 36.8 and $37.9 \%$ lower, respectively, than those of NF soil. Generally, the FD-based soil C and N stocks tend to differ with ESM-based ones, particularly in the surface soil where soil bulk density varies largely, suggesting it is crucial for soil mass correction for estimating SOC and TN stocks with land-use changes. Further study is needed to elucidate the mechanisms behind SOM losses after the landuse conversions in the typical karst landscapes.

Acknowledgements. The authors acknowledge the financial support provided by the National Natural Science Foundation of China (70903061 and 41171440) and Fundamental Research Funds for the Central Universities (no. 2652015175). We also thank the two anonymous referees and editors for their helpful comments and suggestions that greatly improved the manuscript.

Edited by: Artemi Cerdà

Reviewed by: two anonymous referees

\section{References}

Baker, J. M., Ochsner, T. E., Venterea, R. T., and Griffis, T. J.: Tillage and soil carbon sequestration-what do we really know?, Agric. Ecosyst. Environ., 118, 1-5, 2007.

Bao, S. D.: Soil and Agricultural Chemistry Analysis, China Agriculture Press, Beijing, China, 2000 (in Chinese).

Batjes, N. H.: Projected changes in soil organic carbon stocks upon adoption of recommended soil and water conservation practices in the Upper Tana river catchment, Kenya, Land Degrad. Dev., 25, 278-287, 2014.

Brevik, E. C., Cerdà, A., Mataix-Solera, J., Pereg, L., Quinton, J. N., Six, J., and Van Oost, K.: The interdisciplinary nature of SOIL, SOIL, 1, 117-129, doi:10.5194/soil-1-117-2015, 2015.

Carter, M. R.: Soil quality for sustainable land management, Agron. J., 94, 38-47, 2002.

Chen, H., Zhang, W., Wang, K., and Hou, Y.: Soil organic carbon and total nitrogen as affected by land use types in karst and nonkarst areas of northwest Guangxi, China, J. Sci. Food Agric., 92, 1086-1093, 2012.

Costantini, E. A. C., Branquinho, C., Nunes, A., Schwilch, G., Stavi, I., Valdecantos, A., and Zucca, C.: Soil indicators to assess the effectiveness of restoration strategies in dryland ecosystems, Solid Earth, 7, 397-414, doi:10.5194/se-7-397-2016, 2016.

de Moraes Sá, J. C., Séguy, L., Tivet, F., Lal, R., Bouzinac, S., Borszowskei, P. R., Briedis, C., dos Santos, J. B., da Cruz Hartman, D., Bertoloni, C. G., Rosa, J., and Friedrich, T.: Carbon 
depletion by plowing and its restoration by no-till cropping systems in Oxisols of subtropical and tropical Agro-Ecoregions in Brazil, Land Degrad. Dev., 26, 531-543, 2015.

Don, A., Schumacher, J., and Freibauer, A.: Impact of tropical landuse change on soil organic carbon stocks-a meta-analysis, Glob. Change Biol., 17, 1658-1670, 2011.

Ellert, B. H. and Bettany, J. R.: Calculation of organic matter and nutrients stored in soils under contrasting management regimes, Can. J. Soil Sci., 75, 529-538, 1995.

Fialho, R. C. and Zinn, Y. L.: Changes in soil organic carbon under Eucalyptus plantations in Brazil: a comparative analysis, Land Degrad. Dev., 25, 428-437, 2014.

Foley, J. A., DeFries, R., Asner, G. P., Barford, C., Bonan, G., Carpenter, S. R., Chapin, F. S., Coe, M. T., Daily, G. C., Gibbs, H. K., Helkowski, J. H., Holloway, T., Howard, E. A., Kucharik, C. J., Monfreda, C., Patz, J. A., Prentice, I. C., Ramankutty, N., and Snyder, P. K.: Global Consequences of Land Use, Science, 309, 570-574, 2005.

Fu, T., Chen, H., Zhang, W., Nie, Y., and Wang, K.: Vertical distribution of soil saturated hydraulic conductivity and its influencing factors in a small karst catchment in Southwest China, Environ. Monit. Assess., 187, 1-13, 2015.

García-Díaz, A., Allas, R. B., Gristina, L., Cerdà, A., Pereira, P., and Novara, A.: Carbon input threshold for soil carbon budget optimization in eroding vineyards, Geoderma, 271, 144-149, 2016.

Gong, Z.: Soil taxonomy in China: theory, method, practice, Academic Press, Beijing, China, 1999 (in Chinese).

Guo, L. B. and Gifford, R.: Soil carbon stocks and land use change: a meta analysis, Glob. Change Biol., 8, 345-360, 2002.

Harris, N. L., Brown, S., Hagen, S. C., Saatchi, S. S., Petrova, S., Salas, W., Hansen, M. C., Potapov, P. V., and Lotsch, A.: Baseline map of carbon emissions from deforestation in tropical regions, Science, 336, 1573-1576, 2012.

$\mathrm{Hu}, \mathrm{Y} ., \mathrm{Li}, \mathrm{Y}$., and Wang, Q.: Changes in soil fertility after grassland reclamation to farmland in Karst areas of Guangxin Zhuang Autonomous region, B. Soil Water Conserv., 34, 344-348, 2014 (in Chinese).

$\mathrm{Hu}$, Y., Liu, Y., Wu, P., and Zou, X.: Rocky desertification in Guangxi karst mountainous area: its tendency, formation causes and rehabilitation, Transactions of the CSAE, 24, 96-101, 2008 (in Chinese).

Jaiarree, S., Chidthaisong, A., Tangtham, N., Polprasert, C., Sarobol, E., and Tyler, S. C.: Carbon budget and sequestration potential in a sandy soil treated with compost, Land Degrad. Dev., 25, 120-129, 2014.

Janzen, H. H.: Beyond carbon sequestration: soil as conduit of solar energy, Eur. J. Soil Sci., 66, 19-32, 2015.

Jobbágy, E. G. and Jackson, R. B.: The vertical distribution of soil organic carbon and its relation to climate and vegetation, Ecol. Appl., 10, 423-436, 2000.

Lal, R.: Challenges and opportunities in soil organic matter research, Eur. J. Soil Sci., 60, 158-169, 2009.

Lal, R.: Managing soils and ecosystems for mitigating anthropogenic carbon emissions and advancing global food security, Bioscience, 60, 708-721, 2010.

Lee, J., Hopmans, J. W., Rolston, D. E., Baer, S. G., and Six, J.: Determining soil carbon stock changes: Simple bulk density corrections fail, Agric. Ecosyst. Environ., 134, 251-256, 2009.
Liu, F., Wang, S., Liu, Y., He, T., Luo, H., and Long, J.: Changes of soil quality in the process of karst rocky desertification and evaluation of impact on ecological environment, Acta Ecologica Sinica, 25, 639-644, 2005 (in Chinese).

Liu, S., Zhang, W., Wang, K., Pan, F., Yang, S., and Shu, S.: Factors controlling accumulation of soil organic carbon along vegetation succession in a typical karst region in Southwest China, Sci. Total Environ., 521-522, 52-58, 2015a.

Liu, T., Zhao, Z., Lang, Y., and Ding, H.: Profile distribution and accumulation characteristics of organic carbon in a karst hillslope based on particle-size fractionation and stable isotope analysis, J. Environ. Biol., 36, 721-726, 2015 b.

Lozano-García, B. and Parras-Alcántara, L.: Variation in soil organic carbon and nitrogen stocks along a toposequence in a traditional mediterranean olive grove, Land Degrad. Dev., 25, $297-$ 304, 2014.

Mukhopadhyay, S., Masto, R. E., Cerdà, A., and Ram, L. C.: Rhizosphere soil indicators for carbon sequestration in a reclaimed coal mine spoil, Catena, 141, 100-108, 2016.

Olson, K. R. and Al-Kaisi, M. M.: The importance of soil sampling depth for accurate account of soil organic carbon sequestration, storage, retention and loss, Catena, 125, 33-37, 2015.

Parras-Alcántara, L., Lozano-García, B., Brevik, E. C., and Cerdá, A.: Soil organic carbon stocks assessment in Mediterranean natural areas: A comparison of entire soil profiles and soil control sections, J. Environ. Manage., 155, 219-228, 2015.

Post, W. M. and Kwon, K. C.: Soil carbon sequestration and landuse change: processes and potential, Glob. Chang. Biol., 6, 317327,2000 .

Six, J., Callewaert, P., Lenders, S., De Gryze, S., Morris, S. J., Gregorich, E. G., Paul, E. A., and Paustian, K.: Measuring and understanding carbon storage in afforested soils by physical fractionation, Soil Sci. Soc. Am. J., 66, 1981-1987, 2002.

Smith, P., Cotrufo, M. F., Rumpel, C., Paustian, K., Kuikman, P. J., Elliott, J. A., McDowell, R., Griffiths, R. I., Asakawa, S., Bustamante, M., House, J. I., Sobocká, J., Harper, R., Pan, G., West, P. C., Gerber, J. S., Clark, J. M., Adhya, T., Scholes, R. J., and Scholes, M. C.: Biogeochemical cycles and biodiversity as key drivers of ecosystem services provided by soils, SOIL, 1, 665685, doi:10.5194/soil-1-665-2015, 2015.

Sonneveld, B. G. J. S., Keyzer, M. A., and Ndiaye, D.: Quantifying the impact of land degradation on crop production: the case of Senegal, Solid Earth, 7, 93-103, doi:10.5194/se-7-93-2016, 2016.

Srinivasarao, C. H., Venkateswarlu, B., Lal, R., Singh, A. K., Kundu, S., Vittal, K. P. R., Patel, J. J., and Patel, M. M.: Longterm manuring and fertilizer effects on depletion of soil organic carbon stocks under pearl millet-cluster bean-castor rotation in Western India, Land Degrad. Dev., 25, 173-183, 2014.

VandenBygaart, A. J. and Angers, D. A.: Towards accurate measurements of soil organic carbon stock change in agroecosystems, Can. J. Soil Sci., 86, 465-471, 2006.

Wang, S. J., Liu, Q. M., and Zhang, D. F.: Karst rocky desertification in southwestern China: geomorphology, landuse, impact and rehabilitation, Land Degrad. Dev., 15, 115-121, 2004.

Wei, X., Shao, M., Gale, W., and Li, L.: Global pattern of soil carbon losses due to the conversion of forests to agricultural land, Sci. Rep., 4, 4062, doi:10.1038/srep04062, 2014. 
West, T. O. and Post, W. M.: Soil organic carbon sequestration rates by tillage and crop rotation: a global data analysis, Soil Sci. Soc. Am. J., 66, 1930-1946, 2002.

Wiesmeier, M., Lützow, M. v., Spörlein, P., Geuß, U., Hangen, E., Reischl, A., Schilling, B., and Kögel-Knabner, I.: Land use effects on organic carbon storage in soils of Bavaria: the importance of soil types, Soil Till. Res., 146, 296-302, 2015.

Wu, J., Lin, Q., Huang, Q., and Xiao, H.: Soil microbial biomassmethods and application, China Meteorological Press, Beijing, 12, 54-78, 2006 (in Chinese).

Xie, L. W., Zhong, J., Chen, F. F., Cao, F. X., Li, J. J., and Wu, L. C.: Evaluation of soil fertility in the succession of karst rocky desertification using principal component analysis, Solid Earth, 6, 515-524, doi:10.5194/se-6-515-2015, 2015.

$\mathrm{Xu}$, E. Q. and Zhang, H. Q.: Characterization and interaction of driving factors in karst rocky desertification: a case study from Changshun, China, Solid Earth, 5, 1329-1340, doi:10.5194/se5-1329-2014, 2014.
Xu, L., Wang, K., Zhu, H., Hou, Y., and Zhang, W.: Effects of different land use types on soil nutrients in karst region of Northwest Guangxi, Chinese J. Appl. Ecol. 19, 1013-1018, 2008 (in Chinese).

Zhang, W., Wang, K., Chen, H., He, X., and Zhang, J.: Ancillary information improves kriging on soil organic carbon data for a typical karst peak cluster depression landscape, J. Sci. Food Agric., 92, 1094-1102, 2012.

Zhao, J., Li, S., He, X., Liu, L., and Wang, K.: The soil biota composition along a progressive succession of secondary vegetation in a Karst area, PLoS One, 9, e112436, doi:10.1371/journal.pone.0112436, 2014. 